\section{Mummy Berry Disease Blight Resistance in Highbush Blueberry Cultivars}

\author{
A.W. Stretch ${ }^{1}$, M.K. Ehlenfeldt ${ }^{2}$, and V. Brewster ${ }^{3}$ \\ U.S. Department of Agriculture, Agricultural Research Service, Rutgers \\ Blueberry and Cranberry Research Center, Lake Oswego Road, Chatsworth, \\ NJ 08019
}

Additional index words. Vaccinium corymbosum, Monilinia vaccinii-corymbosi, selection method

\begin{abstract}
Fifty-five highbush blueberry (Vaccinium corymbosum L.) cultivars and selections were evaluated over 2 years for their resistance to the shoot blighting phase of mummy berry disease [Monilinia vaccinii-corymbosi (Reade) Honey]. Blight incidence in 1993 ranged from $1 \%$ to $78 \%$ and differences among cultivars were significant. In 1994, infection levels were lower and ranged from $0 \%$ to $43 \%$, again with significant differences among the entries. Several cultivars exhibited mummy berry blight resistance in both years. Ranking most resistant to less resistant were 'Jersey', 'Elliott', 'Bluejay', 'Duke', 'Stanley', 'Darrow', 'Meader', and 'Angola'. Among the cultivars consistently blightsusceptible were 'Bluehaven', 'Bluegold', 'Northblue', 'Croatan', 'Northsky', 'Sierra', 'Harrison', 'Coville', and 'Murphy'. The consistent resistant reaction of certain cultivars indicates that they may be suitable as parents for introducing resistance into a breeding program. The evaluation methodology developed in these tests should be useful in screening germplasm for new sources of resistance and evaluating segregating progeny from crosses.
\end{abstract}

Mummy berry, caused by the fungus Monilinia vaccinii-corymbosi, is the most important widespread fungus disease of blueberry in North America (Eck, 1988). The fungus overwinters as pseudosclerotia or mummified fruit on the soil surface, and in early spring apothecia develop from the pseudosclerotia (Batra, 1983). Primary infection occurs when ascospores, forcibly ejected from apothecia, infect noncuticularized leaf, stem, and flower-bud tissues, causing a blight of the new growth. In the secondary infection phase, conidia produced on the surface of blighted tissue are carried by wind and pollinating insects to flower stigmas where they germinate and grow down the style into the ovary. Fungal tissue colonizes and fills the fruit locules, with no visible exterior symptoms until near harvest when infected berries turn a salmon or cream color, begin to dry up (mummify), and drop to the ground.

Mummy-berry-resistant highbush blueberry cultivars offer an alternative to chemical control that depends on two fungicides, $N, N^{\prime}$ $[1,4-$ p i perazinedi y lbis $(2,2,2$ -

Received for publication 6 Dec. 1994. Accepted for publication $28 \mathrm{Feb}$. 1995. The cost of publishing this paper was defrayed in part by the payment of page charges. Under postal regulations, this paper therefore must be hereby marked advertisement solely to indicate this fact.

${ }^{1}$ Research Plant Pathologist.

${ }^{2}$ Research Geneticist.

${ }^{3}$ Plant Pathologist. trichloroethylidene)]-bis-(formamide) (triforine) and methyl 1-(butylcarbamoyl)-2benzimidazole carbamate (benomyl). Several studies have demonstrated that various levels of resistance to $M$. vaccinii-corymbosi are present in certain highbush blueberry cultivars. However, the results of field studies carried out in British Columbia (Pepin and Toms, 1969), Michigan (Nelson and Bittenbender, 1971), and New Jersey (Varney and Stretch, 1966) were not in complete agreement in their evaluation of a limited group of cultivars.

Our objectives were to develop a reliable method for evaluating highbush blueberry plants for mummy berry blight resistance and to survey a range of cultivars to identify sources of resistance that might be used in a breeding program.

\section{Materials and Methods}

A group of 55 cultivars and selections was assembled as the screening population for this study (Table 1). A few of these selections are not commercially available, but may have breeding value. The selection 11-104 is a sibling of 'Bluecrop' and 'Blueray'; 1613-A is an old selection from Whitesbog, N.J., currently marketed as 'Hardiblue'; 'John Brown' is a drought-tolerant selection made by a New Jersey grower. Selection E-176 (F-72 x 'Berkeley') has good overall mummy berry resistance (Nelson and Bittenbender, 1971). The selection F-72 ('Wareham' $x$ 'Pioneer') is present in the pedigrees of several cultivars. 'Heerma I' and 'Heerma II' are German hybrids that have resistance to Phomopsis.

The plants were set in 3-liter pots in a 1 sand : 1 peat $(\mathrm{v} / \mathrm{v})$ planting mix. Plant height varied from 0.3 to $0.9 \mathrm{~m}$. The test was conducted outdoors as a randomized completeblock design with five replications, and one pot per cultivar per replication. Plants were arranged in a $7 \times 8$ grid pattern in each replication, with $0.45 \mathrm{~m}$ between plants. Six to 12 apothecia/pot, filled with planting mix, were placed so that a source of spores was within 0.3 $\mathrm{m}$ of each plant. Mummies used as inoculum sources were gathered randomly from various blueberry fields at the Rutgers Blueberry and Cranberry Research Center. The entire plot was sprinkler-irrigated ( $25 \mathrm{~mm}$ rainfall equivalent) for $1 \mathrm{~h}$ every evening during ascospore release to enhance infection. Plants were evaluated for number of blighted shoots 14 times between $26 \mathrm{Apr}$. and 14 May 1993 at 1- to 2day intervals. At the end of the blight period, all healthy shoots were counted for each plant so that percent shoot blight could be calculated. Blighted tissue was left on the plants.

The experiment was repeated in 1994 with the addition of 'Nelson' and 'Legacy'. The plants were inspected every 2 days from 12 Apr. to 19 May for blight. In 1994, blighted shoots were counted and, unlike in 1993, removed from the plant at each inspection. All other procedures were as described previously.

The incidence of blight, expressed as the percentage of affected shoots, was subjected to statistical analysis using the general linear model (GLM) procedure of the Statistical Analysis System (SAS Institute, 1989). Means were separated with the Waller-Duncan kratio $t$ test. Correlation analysis was performed using MSTATC statistical analysis software (Michigan State Univ., East Lansing).

\section{Results}

Incidence of shoot blighting differed significantly among entries in both years (Table 1). In 1993, blight incidence ranged from $1 \%$ to $78 \%(\mathrm{~F}=13.79, P<0.05)$. The minimum significant difference for mean separation of genotypes was $14.8 \%$. 'Bluejay', 'Bluetta', 'Darrow', 'Duke', 'Elizabeth', 'Elliott', E176, 'Jersey', 'Pioneer', and 'Stanley' were among the most blight-resistant cultivars ( $<10 \%$ disease incidence) in 1993. 'Bluehaven', 'Bluegold', 'John Brown', 'Blueray', and 'Coville' were among the most susceptible cultivars. The distribution of values was continuous, with no obvious skewing. In 1994, differences also were significant $(\mathrm{F}=$ $12.87, P \leq 0.05)$. Infection levels in 1994 were lower than in 1993, ranging from $0 \%$ to $42.7 \%$; however, the distribution was skewed, with a preponderance of low disease incidence values. The minimum significant difference determined for mean separations $(5.5 \%)$ was $37 \%$ of the value for 1993 , due to the smaller overall variation. In 1994, a group of 45 cultivars with disease incidence ranging from $0 \%$ ('Elliott' and 'Jersey') to $5.0 \%$ ('Cabot') formed a statistically indistinguishable lowinfection group. 'Northblue', with a disease incidence of $42.7 \%$, was at the high end of the rankings. Although infection incidence and distribution patterns differed dramatically be- 
Breeding, Cultivars, Rootstocks, \& Germplasm Resources

Table 1. Percent shoot blighting caused by Monilinia vaccinii-corymbosi on 55 highbush blueberry cultivars.

\begin{tabular}{|c|c|c|c|c|}
\hline \multirow[b]{2}{*}{ Cultivar } & \multicolumn{3}{|c|}{ Blight incidence $(\%)^{2}$} & \multirow[b]{2}{*}{$\begin{array}{c}2-\text { Year } \\
\text { rank (mean) }\end{array}$} \\
\hline & 1993 & 1994 & $\begin{array}{c}2-Y e a r \\
\text { mean }\end{array}$ & \\
\hline Bluehaven & $77.8 a^{x}$ & $22.2 \mathrm{bc}$ & 50.0 & 52.0 \\
\hline Bluegold & $70.7 \mathrm{ab}$ & $27.6 \mathrm{~b}$ & 49.2 & 52.0 \\
\hline John Brown & $69.2 \mathrm{ab}$ & $3.2 \mathrm{f}-\mathrm{h}$ & 36.2 & 42.0 \\
\hline Blueray & $66.7 \mathrm{ab}$ & $2.5 \mathrm{f}-\mathrm{h}$ & 34.6 & 39.5 \\
\hline Coville & $63.4 \mathrm{ab}$ & $3.6 \mathrm{f}-\mathrm{h}$ & 33.5 & 43.0 \\
\hline Sierra & $62.5 \mathrm{bc}$ & $7.4 \mathrm{~d}-\mathrm{f}$ & 35.0 & 46.5 \\
\hline Northblue & $57.8 \mathrm{~b}-\mathrm{d}$ & $42.7 \mathrm{a}$ & 50.2 & 50.0 \\
\hline Croatan & $57.6 \mathrm{~b}-\mathrm{e}$ & $12.6 \mathrm{~d}$ & 35.1 & 47.0 \\
\hline Harrison & $57.5 \mathrm{~b}-\mathrm{e}$ & $12.2 \mathrm{~d}$ & 34.8 & 46.0 \\
\hline Herbert & $56.4 \mathrm{~b}-\mathrm{e}$ & $2.5 \mathrm{f}-\mathrm{h}$ & 16.9 & 31.0 \\
\hline Northsky & $51.5 \mathrm{c}-\mathrm{f}$ & 20.2 c & 35.9 & 46.5 \\
\hline Morrow & $51.2 \mathrm{c}-\mathrm{g}$ & $4.7 \mathrm{e}-\mathrm{h}$ & 28.0 & 41.5 \\
\hline Berkeley & $46.8 \mathrm{~d}-\mathrm{g}$ & $1.6 \mathrm{gh}$ & 24.2 & 31.5 \\
\hline Murphy & $43.3 \mathrm{~d}-\mathrm{h}$ & $9.9 \mathrm{de}$ & 26.6 & 43.0 \\
\hline Bluecrop & $43.0 \mathrm{e}-\mathrm{h}$ & $2.6 \mathrm{f}-\mathrm{h}$ & 22.8 & 35.0 \\
\hline Heerma II & $41.3 \mathrm{f}-\mathrm{i}$ & $6.4 \mathrm{e}-\mathrm{g}$ & 23.9 & 41.0 \\
\hline June & $39.0 \mathrm{f}-\mathrm{j}$ & $4.5 \mathrm{e}-\mathrm{h}$ & 21.8 & 38.5 \\
\hline Atlantic & $37.3 \mathrm{f}-\mathrm{k}$ & $2.3 \mathrm{f}-\mathrm{h}$ & 19.8 & 31.0 \\
\hline Spartan & $36.6 \mathrm{~g}-1$ & $1.6 \mathrm{gh}$ & 19.1 & 28.0 \\
\hline Heerma I & $31.4 \mathrm{~h}-\mathrm{m}$ & $4.5 \mathrm{e}-\mathrm{h}$ & 30.4 & 41.5 \\
\hline Patriot & $27.8 \mathrm{i}-\mathrm{n}$ & $12.8 \mathrm{~d}$ & 20.3 & 41.0 \\
\hline Ivanhoe & $26.9 \mathrm{i}-\mathrm{O}$ & $0.2 \mathrm{~h}$ & 13.5 & 17.5 \\
\hline Northland & $26.8 \mathrm{i}-\mathrm{O}$ & $4.1 \mathrm{f}-\mathrm{h}$ & 15.4 & 34.5 \\
\hline Bluechip & $26.0 \mathrm{j}-\mathrm{O}$ & $2.4 \mathrm{f}-\mathrm{h}$ & 14.2 & 28.5 \\
\hline Weymouth & $24.5 \mathrm{j}-\mathrm{p}$ & $4.7 \mathrm{e}-\mathrm{h}$ & 14.6 & 35.5 \\
\hline 1613-A & $22.7 \mathrm{k}-\mathrm{q}$ & $0.5 \mathrm{~h}$ & 11.6 & 18.5 \\
\hline Sunrise & $22.01-\mathrm{r}$ & $2.6 \mathrm{f}-\mathrm{h}$ & 12.3 & 28.5 \\
\hline Burlington & $21.4 \mathrm{~m}-\mathrm{s}$ & $0.4 \mathrm{~h}$ & 10.9 & 16.0 \\
\hline Lateblue & $20.0 \mathrm{~m}-\mathrm{s}$ & $0.6 \mathrm{~h}$ & 10.3 & 19.0 \\
\hline Toro & $18.7 \mathrm{~m}-\mathrm{s}$ & $1.3 \mathrm{gh}$ & 10.0 & 21.0 \\
\hline Katharine & $17.4 \mathrm{~m}-\mathrm{t}$ & $0.5 \mathrm{~h}$ & 8.9 & 16.0 \\
\hline Dixi & $17.0 \mathrm{~m}-\mathrm{t}$ & $0.2 \mathrm{~h}$ & 8.6 & 13.0 \\
\hline Earliblue & $15.8 \mathrm{n}-\mathrm{u}$ & $1.6 \mathrm{gh}$ & 8.7 & 20.5 \\
\hline $11-104$ & $13.2 \mathrm{n}-\mathrm{V}$ & $0.6 \mathrm{~h}$ & 6.9 & 17.5 \\
\hline Pemberton & $13.2 \mathrm{n}-\mathrm{v}$ & $0.6 \mathrm{~h}$ & 6.9 & 15.5 \\
\hline Rancocas & $13.0 \mathrm{n}-\mathrm{v}$ & $1.4 \mathrm{gh}$ & 7.2 & 18.5 \\
\hline F-72 & $12.3 \mathrm{o}-\mathrm{v}$ & $2.2 \mathrm{f}-\mathrm{h}$ & 7.3 & 21.0 \\
\hline Meader & $12.3 \mathrm{o}-\mathrm{v}$ & $0.4 \mathrm{~h}$ & 6.3 & 10.5 \\
\hline Angola & $12.2 \mathrm{o}-\mathrm{V}$ & $0.5 \mathrm{~h}$ & 6.3 & 12.0 \\
\hline Harding & $10.8 \mathrm{p}-\mathrm{v}$ & $3.0 \mathrm{f}-\mathrm{h}$ & 6.9 & 23.0 \\
\hline Cabot & $10.7 \mathrm{p}-\mathrm{v}$ & $5.0 \mathrm{e}-\mathrm{h}$ & 7.9 & 28.0 \\
\hline Rubel & $10.6 \mathrm{p}-\mathrm{V}$ & $1.8 \mathrm{gh}$ & 6.2 & 17.5 \\
\hline Wareham & $10.0 \mathrm{p}-\mathrm{V}$ & $3.3 \mathrm{f}-\mathrm{h}$ & 6.7 & 22.5 \\
\hline E-176 & $9.0 \mathrm{q}-\mathrm{v}$ & $1.1 \mathrm{gh}$ & 5.1 & 13.5 \\
\hline Elizabeth & $8.4 \mathrm{q}-\mathrm{v}$ & $1.9 \mathrm{gh}$ & 5.1 & 16.5 \\
\hline Bluetta & $7.6 \mathrm{r}-\mathrm{v}$ & $3.5 \mathrm{f}-\mathrm{h}$ & 5.5 & 22.0 \\
\hline Stanley & $7.1 \mathrm{~s}-\mathrm{v}$ & $0.4 \mathrm{~h}$ & 3.8 & 9.0 \\
\hline Elliott & $6.7 \mathrm{~s}-\mathrm{v}$ & $0.0 \mathrm{~h}$ & 3.3 & 3.8 \\
\hline Darrow & $6.6 \mathrm{~s}-\mathrm{v}$ & $1.0 \mathrm{gh}$ & 3.8 & 10.5 \\
\hline Pioneer & $3.8 \mathrm{t}-\mathrm{v}$ & $3.4 \mathrm{f}-\mathrm{h}$ & 3.6 & 19.5 \\
\hline Duke & $2.9 \mathrm{t}-\mathrm{v}$ & $0.6 \mathrm{~h}$ & 1.8 & 8.5 \\
\hline Jersey & $1.8 \mathrm{uv}$ & $0.0 \mathrm{~h}$ & 0.9 & 1.8 \\
\hline Bluejay & $1.0 \mathrm{v}$ & $0.4 \mathrm{~h}$ & 0.3 & 4.0 \\
\hline Legacy & --- & $3.7 \mathrm{f}-\mathrm{h}$ & --- & --- \\
\hline Nelson & --- & $0.2 \mathrm{~h}$ & --- & --- \\
\hline
\end{tabular}

${ }^{2}$ Average percent incidence across five plants per cultivar.

'Mean of 1993 and 1994 ranks as determined for Spearman's rank correlation test.

${ }^{x}$ Means separated with Waller-Duncan k-ratio $t$ test at $P \leq 0.05$.

tween the two years, disease incidences were significantly correlated $(r=0.590, P<0.001$, Spearman's rank correlation). Across the two years, several cultivars were consistently ranked as being blight resistant (Table 1). From most resistant $(0.3 \%)$ to least resistant $(6.3 \%)$ were 'Bluejay', 'Jersey', 'Elliott', 'Duke', 'Stanley', 'Darrow', 'Meader', and 'Angola'. Among the consistently blight-susceptible cultivars (ranging from $50 \%$ to $33.5 \%$ incidence) were 'Bluehaven', 'Bluegold', 'Northblue', 'Croatan', 'Northsky', 'Sierra', resistance to the shoot blighting phase of mummy berry disease, although this variability appears to be influenced by environmental differences between years. The levels of infection across generally unrelated cultivars formed a continuous distribution, suggesting that resistance is not conditioned by major genes. Little more can be concluded about the genetic basis for resistance or susceptibility without inheritance studies. Certain cultivars consistently rated as resistant, suggesting that they would be good parents for introducing resistance into a breeding program.

Our results conflict with some reports from the literature. Varney and Stretch (1966) and Pepin and Toms (1969) rated 'Earliblue' as susceptible; however, in this study it had $8.7 \%$ of its shoots infected, which was not statistically different from the most resistant cultivars. Nelson and Bittenbender (1971) rated 'Earliblue' as resistant. 'Rancocas' was used by Pepin and Toms (1969) as a susceptible control and was rated moderately susceptible by Varney and Stretch (1966), but in this study, with $7.2 \%$ of it shoots infected, it was not statistically different from the most resistant cultivars. Nelson and Bittenbender (1971) rated 'Coville' and 'Spartan' as resistant. In 1993, 'Spartan' fell between the most resistant and the most susceptible cultivars $(36.6 \%$ infected), but in 1994 it appeared resistant (1.6\% infected). In 1993, 'Coville' was among the most susceptible (63.4\% infected); however, in 1994 (at 3.6\%) it was not statistically different from the most resistant cultivars. Varney and Stretch (1966) rated 'Pioneer' as susceptible, but it was among the most resistant cultivars for both years in this study. These results highlight the fact that the incidence for certain cultivars may vary with disease pressure or environmental conditions. However, the results of Nelson and Bittenbender (1971) were based on what appears to be a rather low incidence of twig blighting, which may result in more escapes. Moreover, these studies represent three different geographical and climatic environments: British Columbia (Pepin and Toms, 1969), Michigan (Nelson and Bittenbender, 1971), and New Jersey. Locations may vary not only in environments, but also in strains of the pathogen. Within our 2year study, we saw substantial year-to-year differences, possibly due to environmental effects on pathogen-plant interactions. Winter 1993-94 was colder than that of 1992-93, with minima below $-15 \mathrm{C}$ on 7 days, as compared to 0 days in 1992-93. Heat-unit accumulation during the blight infection period was less in 1993 (96 units) than in 1994 (191 units). Apothecial development may have been further advanced in 1994 than 1993 in relation to plant development, thus reducing inoculum on later-emerging cultivars in 1994. This situation may explain the skewing of percent blight toward low incidence of infection in 1994. The variation between years also emphasizes the importance of high disease pressure to make effective comparisons for resistance.

In blueberry, little is known regarding the mechanism of resistance to blighting by 
mummy berry. Interactions of cultivar, pathogen, and environment may affect disease levels, as may dispersion of spores. We tried in this study to assure that inoculum was present over an extended period of time, so that escapes were, presumably, minimized. Further studies are needed to determine the nature of resistance and to identify usable germplasm for breeding.

\section{Literature Cited}

Batra, L.R. 1983. Monilinia vaccinii-corymbosi (Sclerotiniaceae): Its biology on blueberry and comparison with related species. Mycologia 75:131-152.

Eck, P. 1988. Blueberry science. Rutgers Univ. Press, New Brunswick, N.J.

Nelson, J. and H.C. Bittenbender. 1971. Mummy berry disease occurrence in a blueberry se- lection test planting. Plant Dis. Rptr. 55:651653.

Pepin, H.S. and H.N.W. Toms. 1969. Susceptibility of highbush blueberry varieties to Monilinia vaccinii-corymbosi. Phytopathology 59:18761878.

Varney, E.H. and A.W. Stretch. 1966. Diseases and their control, p. 236-279. In: P. Eck and N.F. Childers (eds.). Blueberry culture. Rutgers Univ. Press, New Brunswick, N.J. 